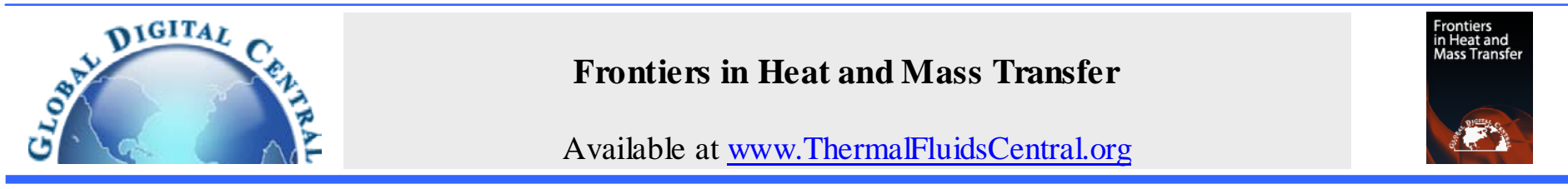

\title{
A CRITICAL REVIEW OF RECENT INVESTIGATIONS ON TWO-PHASE PRESSURE DROP IN FLOW BOILING MICRO-CHANNELS
}

\author{
Sira Saisorn $^{\mathrm{a}, \mathrm{b}}$, Somchai Wongwises ${ }^{\mathrm{b}, \mathrm{c} *}$ \\ ${ }^{a}$ King Mongkut's Institute of Technology Ladkrabang Chumphon Campus Chumphon 86160, Thailand \\ ${ }^{b}$ Fluid Mechanics, Thermal Engineering and Multiphase Flow Research Lab. (FUTURE) \\ Department of Mechanical Engineering, King Mongkut's University of Technology Thonburi, Bangmod, Bangkok 10140, Thailand \\ ${ }^{c}$ The Academy of Science, The Royal Institute of Thailand, Sanam Suea Pa, Dusit, Bangkok 10300, Thailand
}

\begin{abstract}
Two-phase pressure drop during flow boiling has been studied for several decades. Obviously, the publications available on micro-channels are relatively small compared with those for ordinarily sized channels. Although the use of micro-channels yields several advantages, the pressure drop takingp lace in these extremely small channels is higher than that in the ordinarily sized channels because of the increased wall friction. The knowledge of the two-phase pressure drop characteristics in addition to heat transfer phenomena is essential to the design and evaluation of the micro-systems. In this paper, recent research on the flow boiling pressure drop in micro-scale channels is reviewed. The experimental results as well as the relevant prediction methods based on different researchers are presented.
\end{abstract}

Keywords: flow boiling, micro-channel, pressure drop, heat transfer

\section{INTRODUCTION}

In the past 10 years, investigations on flow boiling heat transfer and flow characteristics in micro-channel flow passages have gained significant attention in engineering community. Because of their large heat transfer surface area, the utilization of micro-channels can result in relatively high heat transfer coefficient when compared with the application of ordinarily sized channels. Flow boiling in microchannel has been applied to energy and process systems including high heat-flux compact heat exchangers, and cooling devices of various types of equipment such as high performance microelectronics, high-powered lasers, and so on.

Although there are several advantages arising in micro-channel applications, a considerable penalty is relatively high pressure drop due to the increased wall friction, resulting in the increment of power consumption. The applicable range of the flow in miniature devices is restricted by this main drawback. It is therefore important to understand pressure drop characteristics in addition to heat transfer phenomena in micro-channels, which is of necessity for operating and evaluating the system performance.

A scaling analysis of different forces, as recently discussed in Kandlikar (2010), pointed out that surface tension and evaporation momentum forces were significant for two-phase flow phenomena at micro-scale, resulting in the flow behaviors substantially different from those of ordinarily sized channels.

Currently, it seems rather vague to identify whether or not the flow passages are micro-channels. The followings are some important tentative criterions which are given in brief.

The criteria based on different dimensionless parameters have been proposed in the literature. The confinement number recommended by Kew and Cornwell (1997) was proposed to be

*Corresponding author: E-mail: somchai.won@kmutt.ac.th related with some physical aspects of flow boiling. The confinement number is defined as

$C_{o}=\frac{D_{b}}{D_{h}}$

where $D_{h}$ is hydraulic diameter and $D_{b}$ is nominal bubble size or capillary length which is expressed by

$D_{b}=\sqrt{\frac{\sigma}{g\left(\rho_{L}-\rho_{G}\right)}}$

The confinement number above 0.5 implies that the micro-scale effects are important for a given channel diameter. In Eq.(2), $\sigma$ stands for surface tension, $g$ is gravitational acceleration, $\rho_{\mathrm{L}}$ and $\rho_{\mathrm{G}}$ are, respectively, liquid and vapour densities.

Based on 4228 data points gathered from the literature, $\mathrm{Li}$ and Wu (2010a) showed the transitional threshold from macro- to microchannels during flow boiling to be represented as a combined nondimensional number, $B_{0} \times \operatorname{Re}_{L}^{0.5}=200 . \quad B_{0}$ and $\operatorname{Re}_{L}$ stand, respectively, for Bond number and liquid Reynolds number. The micro-scale effects are dominant when such combined nondimensional number is lower than 200.

It is interesting to note from Tibirica and Ribatski (2010) that the channel with a diameter of $2.3 \mathrm{~mm}$ was considered as the one in which the transition between macro- and micro-scale flow boiling phenomena took place when halocarbon refrigerants were used as working fluids under Earth's gravity. With visualization study, they detected stratification effects in this channel size. Recently, Ong and 
Thome (2011) investigated experiments to address the macro-tomicro-scale transition for flow boiling of refrigerants in different channel sizes. They indicated the dependence of the threshold of the transition on flow regime and confinement number. As illustrated in Fig. 1, the lower threshold of macro-scale flow corresponded to confinement number ranging from 0.3 to 0.4 whereas the confinement number of around 1.0 stood for the upper threshold of micro-scale flow. It was noted that the transition region, frequently corresponding to as mini-channels in literature, was located in between the two boundaries.

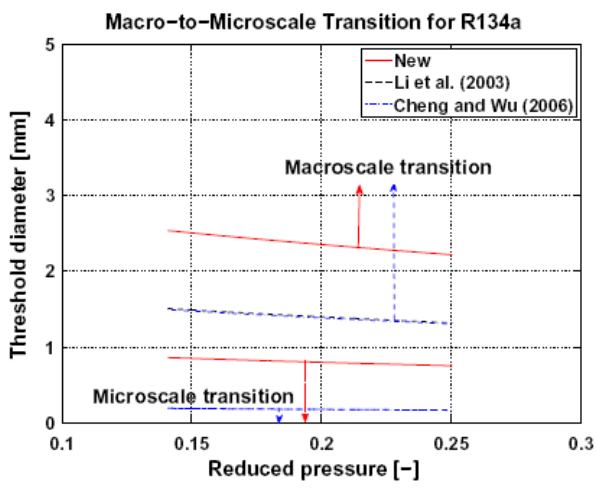

Fig. 1 Transition criterion of Ong and Thome (2011). "Reprinted from Experimental Thermal and Fluid Science, 35(1), Ong, C.L., and Thome, J.R., Macro-to-microchannel transition in two-phase flow: Part 1-Two-phase flow patterns and film thickness measurements, pp. 37-47 (2011), with permission from Elsevier.”

Noting from Kandlikar (2010) that as the mass flux substantially increases, the inertia force becomes larger and tends to be of importance as shown in Fig. 2. In the region of very high mass flux, therefore, the inertia force in addition to surface tension and buoyancy (gravity) forces should be taken into account for developing the criteria.

Despite a number of criteria being proposed, a clear physical criterion that relates the channel diameter to the fluid flow mechanisms is still not available and, hence, further investigation should be performed to meet a more general definition dealing with channel classification.

\section{TW O-PHAS E PRESS URE DROP}

Although there are several advantages arising in micro-channel applications, a considerable penalty is relatively high pressure drop, due to the increased wall friction, when compared with the ordinarily sized channels. It is therefore important to understand pressure drop characteristics in addition to heat transfer phenomena in microchannels, which is of necessity for operating and evaluating the system performance.

Recent studies dealing with flow boiling pressure drop characteristics, excluding flow instability, in micro-channels are reviewed in this section. During the past years, investigations of twophase pressure drop during micro-scale flow have been published in the literature and Table 1 lists the selected investigations recently done by various researchers.

Two-phase pressure drop across micro-channels were measured by Lee and Mudawar (2005). Flow boiling of R-134a in rectangular channels was established in their study. The measured pressure drops were not well predicted by the existing correlations. To improve the accuracy of the prediction, the parameters including liquid viscosity and surface tension were incorporated in their correlation as seen in Eqs.(3) and (4).

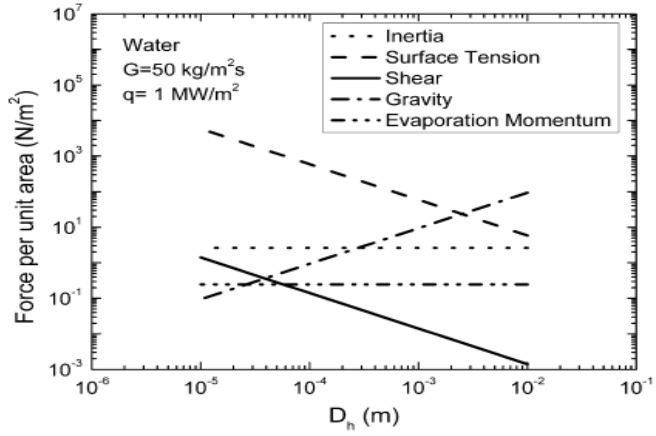

(a)

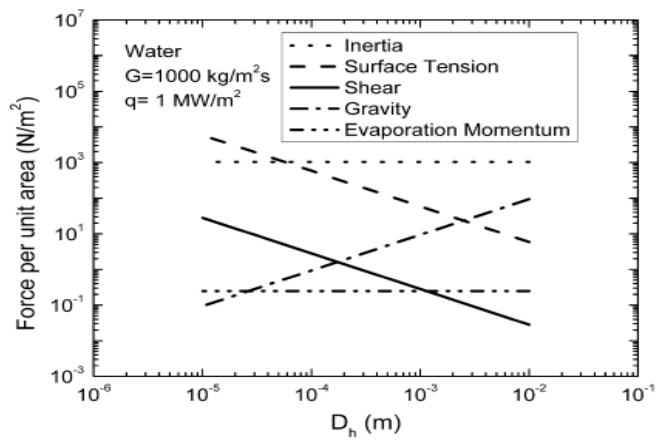

Fig. 2 Scale effect of tube diameter on various forces during flow boiling by Kandlikar (2010). "Reprinted from International Journal of Thermal Science, 49(7), Kandlikar, S.G., Scale effects on flow boiling heat transfer in microchannels: A fundamental perspective, pp. 1073-1085 (2010), with permission from Elsevier.”

For laminar liquid-laminar vapour flow:

$\phi_{\mathrm{L}}^{2}=1+\frac{2.16 \mathrm{Re}_{\mathrm{LO}}^{0.047} \mathrm{We}_{\mathrm{LO}}^{0.6}}{\chi}+\frac{1}{\chi^{2}}$

For laminar liquid-turbulent vap our flow:

$\phi_{\mathrm{L}}^{2}=1+\frac{1.45 \mathrm{Re}_{\mathrm{LO}}^{0.25} \mathrm{We}_{\mathrm{LO}}^{0.23}}{\chi}+\frac{1}{\chi^{2}}$

Lee and Garimella (2008) experimentally investigated twophase pressure drop in rectangular micro-channels. The measured pressure drop strongly depended on heat flux. The comparisons between the experimental data and the existing correlations were discussed. They also proposed a correlation for pressure drop prediction based on the method by Mishima and Hibiki (1996) as follows.

$\phi_{\mathrm{L}}^{2}=1+\frac{2566 \mathrm{G}^{0.5466} \mathrm{D}_{\mathrm{h}}^{0.8819}\left(1-\mathrm{e}^{-319 \mathrm{D}_{\mathrm{h}}}\right)}{\chi_{\mathrm{vv}}}+\frac{1}{\chi_{\mathrm{vv}}^{2}}$

For laminar liquid-laminar vapour flow, the Martinelli parameter is expressed as

$\chi_{\mathrm{vv}}=\left(\frac{1-\mathrm{x}}{\mathrm{x}}\right)^{0.5}\left(\frac{\rho_{\mathrm{G}}}{\rho_{\mathrm{L}}}\right)^{0.5}\left(\frac{\mu_{\mathrm{L}}}{\mu_{\mathrm{G}}}\right)^{0.5}$

Choi et al. (2008) performed flow boiling pressure drop experiments. R-410A was used as working fluid flowing in stainless steel tubes with diameters of 1.5 and $3 \mathrm{~mm}$. The results indicated that the two-phase pressure drop increased with the increase in mass flux 
Table 1 Summary of recent investigations on pressure drop during micro-scale flow boiling

\begin{tabular}{|c|c|c|c|}
\hline Reference & $\begin{array}{l}\text { Fluid and parameter ranges } \\
\mathrm{G}\left[\mathrm{kg} / \mathrm{m}^{2} \mathrm{~s}\right], \mathrm{q}\left[\mathrm{kW} / \mathrm{m}^{2}\right] \\
\mathrm{P}[\mathrm{kPa}], \mathrm{T}\left[{ }^{\mathrm{O}} \mathrm{C}\right]\end{array}$ & $\begin{array}{l}\text { Channel geometry/ } \\
\text { substrate/orientation/ } \\
\text { diameter }[\mathrm{mm}]\end{array}$ & Remarks \\
\hline $\begin{array}{l}\text { Lee and } \\
\text { Mudawar (2005) }\end{array}$ & $\begin{array}{l}\mathrm{R}-134 \mathrm{a} \\
\mathrm{G}=127-654, x=0.001-0.25 \\
q=316-938 \\
P_{\text {in }}=144-660\end{array}$ & $\begin{array}{l}53 \text { parallel rectangular/ } \\
\text { copper/horizontal/ } \\
\mathrm{D}_{\mathrm{h}}=0.35\end{array}$ & $\begin{array}{l}\text { The prop osed correlation incorporated } \\
\text { liquid viscosity and surface tension } \\
\text { effects. }\end{array}$ \\
\hline $\begin{array}{l}\text { Lee and } \\
\text { Garimella (2008) }\end{array}$ & $\begin{array}{l}\text { water } \\
\mathrm{G}=368-738, \mathrm{x}=0-0.2 \\
\mathrm{q}=100-3400 \\
\mathrm{~T}_{\text {in }}=90.6-95.1\end{array}$ & $\begin{array}{l}10-60 \text { parallel rectangular/ } \\
\text { silicon/horizontal/ } \\
\mathrm{D}_{\mathrm{h}}=0.16-0.54\end{array}$ & $\begin{array}{l}\text { Pressure drop strongly depended on heat } \\
\text { flux. }\end{array}$ \\
\hline $\begin{array}{l}\text { Choi et al. } \\
\text { (2008) }\end{array}$ & $\begin{array}{l}R-410 A \\
G=300-600, x=0-1 \\
q=10-40 \\
T_{\text {in }}=10\end{array}$ & $\begin{array}{l}\text { Single circular/stainless } \\
\text { steel/horizontal/ } \\
\mathrm{D}=1.5,3\end{array}$ & $\begin{array}{l}\text { Pressure drop increased with increasing } \\
\text { mass flux and vapour quality. }\end{array}$ \\
\hline $\begin{array}{l}\text { Pamitran et al. } \\
\text { (2008) }\end{array}$ & $\begin{array}{l}\mathrm{CO}_{2} \\
\mathrm{G}=200-600 \\
\mathrm{q}=10-30 \\
\mathrm{~T}_{\text {sat }}=-10,-5,10\end{array}$ & $\begin{array}{l}\text { Single circular/stainless } \\
\text { steel/horizontal/ } \\
\mathrm{D}=1.5,3\end{array}$ & $\begin{array}{l}\text { Channel diameter, mass flux, surface } \\
\text { tension, density and viscosity had } \\
\text { influence on pressure drop. }\end{array}$ \\
\hline $\begin{array}{l}\text { Agostini et al. } \\
(2008)\end{array}$ & $\begin{array}{l}R-236 f a \\
G=276-992, x=0.5-1.0 \\
q=1120-2500 \\
T_{\text {sat }}=20.31-34.27\end{array}$ & $\begin{array}{l}66 \text { parallel rectangular/ } \\
\text { silicon/horizontal/ } \\
\mathrm{D}_{\mathrm{h}}=0.336\end{array}$ & $\begin{array}{l}\text { Homogen eous flow model worked well } \\
\text { with the measured pressure drop. }\end{array}$ \\
\hline $\begin{array}{l}\text { Singh et al. } \\
(2008)\end{array}$ & $\begin{array}{l}\text { water } \\
G=82-126, x=0.29 \\
q=290-366\end{array}$ & $\begin{array}{l}\text { Single rectan gular/silicon/ } \\
\text { horizontal/ } \\
\mathrm{D}_{\mathrm{h}}=0.142\end{array}$ & $\begin{array}{l}\text { Two-phase pressure drop was found to be } \\
\text { lower than the single-phase value when a } \\
\text { certain mass flux and heat flux range was } \\
\text { established. }\end{array}$ \\
\hline Lie et al. (2008) & $\begin{array}{l}\text { R-134a, R-407C } \\
G=200-400, x=0.2-0.8 \\
q=5-15 \\
T_{\text {sat }}=5-15\end{array}$ & $\begin{array}{l}28 \text { parallel circular/ } \\
\text { copper/horizontal/ } \\
\mathrm{D}=0.83,2\end{array}$ & $\begin{array}{l}\text { The use of R-134a as working fluid } \\
\text { caused pressure drop relatively high in } \\
\text { comparison to R-407C }\end{array}$ \\
\hline $\begin{array}{l}\text { Choi et al. } \\
\text { (2009) }\end{array}$ & $\begin{array}{l}\mathrm{C}_{3} \mathrm{H}_{8} \\
\mathrm{G}=50-400, x=0-1 \\
q=5-20 \\
\mathrm{~T}_{\text {sat }}=0,5,10\end{array}$ & $\begin{array}{l}\text { Single circular/stainless } \\
\text { steel/horizontal/ } \\
\mathrm{D}=1.5,3\end{array}$ & $\begin{array}{l}\text { An increase in mass flux or heat flux } \\
\text { resulted in higher pressure drop. }\end{array}$ \\
\hline $\begin{array}{l}\text { Coppetti et al. } \\
\text { (2011) }\end{array}$ & $\begin{array}{l}\mathrm{R}-134 \mathrm{a} \\
\mathrm{G}=240-930, \mathrm{x}=0-0.8 \\
\mathrm{q}=10-100 \\
\mathrm{~T}_{\text {sat }}=12,22\end{array}$ & $\begin{array}{l}\text { Single circular/stainless } \\
\text { steel/horizontal/ } \\
\mathrm{D}=2.62\end{array}$ & $\begin{array}{l}\text { Pressure drop depended on mass flux and } \\
\text { vap our quality. }\end{array}$ \\
\hline $\begin{array}{l}\text { Soupremanien et } \\
\text { al. (2011) }\end{array}$ & $\begin{array}{l}\text { Forane }^{\circledR} 365 \mathrm{HX} \\
\mathrm{G}=200-400, \mathrm{x}=0-0.6 \\
\mathrm{q}=25-62 \\
\mathrm{~T}_{\text {sat }}=56\end{array}$ & $\begin{array}{l}\text { Single rectangular/stainless } \\
\text { steel/horizontal/ } \\
\mathrm{D}_{\mathrm{h}}=1.4\end{array}$ & $\begin{array}{l}\text { Pressure drop characteristics were } \\
\text { affected by aspect ratio. }\end{array}$ \\
\hline $\begin{array}{l}\text { Costa-Patry et al. } \\
\text { (2011) }\end{array}$ & $\begin{array}{l}\text { R-236fa, R-245fa } \\
G=499-1100, x=0.03-0.53 \\
q=130-1400 \\
T_{\text {sat }}=30.5\end{array}$ & $\begin{array}{l}135 \text { parallel rectangular/ } \\
\text { silicon/horizontal/ } \\
\mathrm{D}_{\mathrm{h}}=0.148\end{array}$ & $\begin{array}{l}\text { The experimental technique was } \\
\text { presented to measure the outlet pressure } \\
\text { losses. }\end{array}$ \\
\hline
\end{tabular}


and vapour quality. The pressure drop was also strongly dependent on the channel diameter.

The two-phase pressure drop experiments similar to Choi et al. (2008) were carried out by Pamitran et al. (2008). The stainless steel tubes having diameters of 1.5 and $3 \mathrm{~mm}$ were used as test sections in which flow vapourization of $\mathrm{CO}_{2}$ was established. According to their experimental data, the pressure drop was in relation with channel diameter, mass flux, surface tension, density and viscosity.

Agostini et al. (2008) carried out experiments to investigate pressure drop of R-236fa and R-245fa during flow boiling in microchannels. They reported that flow boiling of R-245fa induced pressure drop higher than R-236fa. The prediction method on the basis of homogeneous flow assumption predicted well their measured results.

Singh et al. (2008) investigated two-phase pressure drop characteristics for flow boiling of water in micro-channels with different aspect ratios. All test sections had rectangular cross-section having a constant hydraulic diameter of $142 \mu \mathrm{m}$. The experiments were performed for the aspect ratio range of 1.23 to 3.75. The aspect ratio of around 1.56 provided the minimum two-phase pressure drop. Moreover, at this value of aspect ratio, the two-phase pressure drop was found to be lower than the single-phase value when a certain condition was established as presented in Fig. 3.

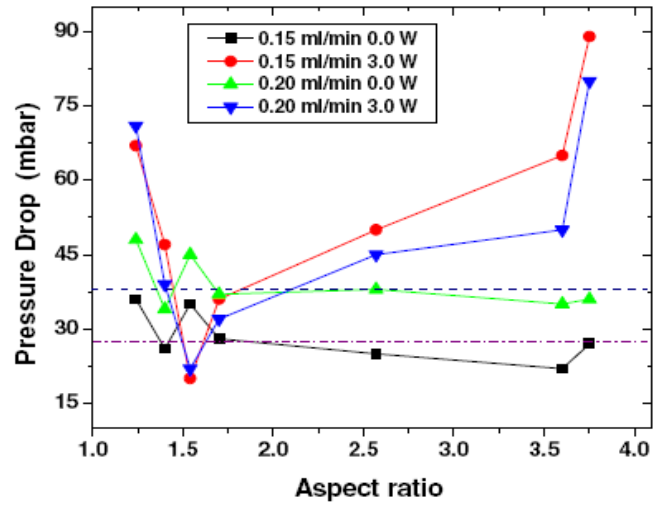

Fig. 3 Pressure drop data of Singh et al. (2008). "Reprinted from Experimental Thermal and Fluid Science, 33(1), Singh, S.G., Kulkarni, A., Duttagupta, S.P., Puranik, B.P., and Agrawal, A., Impact of aspect ratio on flow boiling of water in rectangular microchannels, pp. 153-160 (2008), with permission from Elsevier."

Lie et al. (2008) studied experimentally flow boiling of refrigerants in micro-channels. The frictional pressure drop characteristics of R-134a and R-407C were reported in their work. The results showed the increase in pressure drop with increasing vapour quality and mass flux. The reduction in pressure drop was observed as the saturation temperature was increased. In their study, the pressure drop was less dependent with heat flux. The use of R$134 \mathrm{a}$ as working fluid caused pressure drop relatively high in comparison to R-407C. They also proposed pressure drop correlation in the form of friction factor as expressed below.

$\mathrm{f}_{\text {TP }}=-0.037-147341 \mathrm{Re}_{\text {eq }}^{-1.859}+0.039 \mathrm{C}_{\mathrm{o}}^{-0.508}+327726 \mathrm{Re}_{\mathrm{eq}}^{-1.859} \mathrm{C}_{\mathrm{o}}^{-0.508}$

$\mathrm{Re}_{\mathrm{eq}}$ in the above equation refers to equivalent Reynolds number expressed as

$\operatorname{Re}_{\mathrm{eq}}=\frac{\mathrm{G}_{\mathrm{eq}} \mathrm{D}_{\mathrm{h}}}{\mu_{\mathrm{L}}}$

The equivalent mass flux, $\mathrm{G}_{\text {eq }}$, is determined by
$G_{\text {eq }}=G\left[\left(1-x_{\text {in }}\right)+x_{\text {in }}\left(\frac{\rho_{L}}{\rho_{G}}\right)^{0.5}\right]$

Pressure drop during flow boiling of propane in horizontal channels was studied by Choi et al. (2009). An increase in mass flux or heat flux resulted in the higher pressure drop. A decrease in channel diameter, corresponding to a higher wall shear stress, leaded to an increase in the pressure drop. They indicated that the lower the saturation temperature, the higher was the pressure drop, which was explained according to the change in density and viscosity. In addition, they developed a pressure drop correlation on the basis of the Lockhart-Martinelli method and the Chisholm parameter was proposed by the following equation.

$\mathrm{C}=1732.953 \mathrm{Re}_{\mathrm{TP}}^{-0.323} \mathrm{We}_{\mathrm{TP}}^{-0.24}$

Sun and Mishima (2009) analysed 2092 data points collected from several previous studies. They found that in laminar flow region $\left(\operatorname{Re}_{\mathrm{L}}<2000\right.$ and $\left.\operatorname{Re}_{\mathrm{G}}<2000\right)$, the Chisholm parameter was found to be significantly affected by liquid Reynolds number and confinement number, and expressed as follow.

$C=26\left(1+\frac{\operatorname{Re}_{L}}{1000}\right)\left[1-\mathrm{e}^{\left(\frac{-0.153}{0.27 \mathrm{C}_{\mathrm{o}}+0.8}\right)}\right]$

For $\mathrm{Re}_{\mathrm{L}}>2000$ or $\mathrm{Re}_{\mathrm{G}}>2000$, the ratio of $\mathrm{Re}_{\mathrm{G}}$ to $\mathrm{Re}_{\mathrm{L}}$ was found to play dominant role on the Chisholm correlation which was modified as presented below.

$\phi_{\mathrm{L}}^{2}=1+\frac{1.79\left(\frac{\mathrm{Re}_{\mathrm{G}}}{\mathrm{Re}_{\mathrm{L}}}\right)^{0.4}\left(\frac{1-\mathrm{x}}{\mathrm{x}}\right)^{0.5}}{\chi^{1.19}}+\frac{1}{\chi^{2}}$

Zhang et al. (2010) proposed correlations for two-phase flow in micro-channels. The Chisholm parameter needed for pressure drop calculations was correlated by the following equations.

For boiling flow:

$\mathrm{C}=21\left[1-\mathrm{e}^{\left(\frac{-0.358}{\mathrm{C}_{\mathrm{o}}}\right)}\right]$

For two-phase gas-liquid adiabatic flow:

$\mathrm{C}=21\left[1-\mathrm{e}^{\left(\frac{-0.674}{\mathrm{C}_{\mathrm{o}}}\right)}\right]$

For two-phase vapour-liquid adiabatic flow:

$C=21\left[1-\mathrm{e}^{\left(\frac{-0.142}{\mathrm{C}_{\mathrm{o}}}\right)}\right]$

These correlations were developed based on the method of Mishima and Hibiki (1996). Remarkably, the above correlations are applicable when the experimental conditions comply with the following ranges; $0.014 \leq \mathrm{D}_{\mathrm{h}} \leq 6.25 \mathrm{~mm}, \mathrm{Re}_{\mathrm{L}} \leq 2000$ and $\mathrm{Re}_{\mathrm{G}} \leq$ 2000.

Referring to the above three equations, the relevant processes were defined as follows. The gas-liquid adiabatic flow was denoted as two fluids without heat and mass transfers. The vapour-liquid adiabatic flow was dealt only with one fluid appearing in two-phase condition. Flow boiling represented the most complex two-phase flow pertaining to thermal and hydraulic coupling. 
The experimental investigation for R-134a refrigerant during flow boiling in a tube having a diameter of $1.75 \mathrm{~mm}$ was performed by Saisorn et al. (2010). They reported that the lower liquid viscosity due to the increment of saturation pressure lead to the decrease in frictional pressure drop.

Lee et al. (2010) reported that Bond number and outlet vapour quality play ed important role on the pressure drop prediction for flow boiling in micro-channels. They also proposed the correlation as seen below.

$\phi_{\mathrm{L}}^{2}=1+\frac{121.6\left(1-\mathrm{e}^{-22.7 \lambda}\right) \mathrm{x}_{\text {out }}^{1.85}}{\chi}+\frac{1}{\chi^{2}}$

The two-phase pressure drop characteristics in micro-channels were reported by $\mathrm{Li}$ and $\mathrm{Wu}$ (2010b). Concerning the database containing 769 data points available in the literature, they indicated the significant role of Bond number on the pressure drop prediction, and the Chisholm parameter was modified as follows.

$\mathrm{C}=11.9 \mathrm{~B}_{\mathrm{o}}^{0.45} ; \quad \mathrm{B}_{\mathrm{o}} \leq 1.5$

$\mathrm{C}=109.4\left(\mathrm{~B}_{\mathrm{o}} \operatorname{Re}_{\mathrm{L}}^{0.5}\right)^{-0.56} ; 1.5<\mathrm{B}_{\mathrm{o}} \leq 11$

For Bond number greater than 11, there was no obvious relationship between the Chisholm parameter and the Bond number. In such region $\left(B_{0}>11\right)$, however, they recommended the Beattie and Whalley correlation (1982), which is prediction method based on homogeneous flow assumption, as a good choice for predicting the pressure drop. As also reported by Ribatski et al. (2006) and Revellin et al. (2006), the methods on the basis of homogeneous flow model were able to tentatively apply for micro-channels under a certain range of experimental condition. Moreover, the homogeneous flow model was adopted by Chen et al. (2009) and Wang et al. (2010) to predict the pressure drop for two-phase flow through abrupt area change.

The correlation for two-phase pressure change due to sudden expansion in small flow passages was proposed by Wang et al. (2010). With 282 data collected from the literature, their prediction method based on the modified homogeneous model is given by the following equation.

$\Delta \mathrm{P}_{\mathrm{e}}=\mathrm{G}^{2} \sigma_{\mathrm{A}}\left(1-\sigma_{\mathrm{A}}\right)\left[\frac{(1-\mathrm{x})}{\rho_{\mathrm{L}}}+\frac{\mathrm{x}}{\rho_{\mathrm{G}}}\right]\left(1+\Omega_{1}-\Omega_{2}\right)\left(1+\Omega_{3}\right)$

where $\sigma_{\mathrm{A}}$ represents flow cross-sectional area expansion ratio, 0 $<\sigma_{\mathrm{A}}<1$, and the correction factors, $\Omega_{1}, \Omega_{2}$, and $\Omega_{3}$, are expressed as follows.

$\Omega_{1}=\frac{1}{\mathrm{Fr}^{0.8}}\left(\frac{\mathrm{We} \times \mathrm{B}_{\mathrm{o}}}{\operatorname{Re}_{\mathrm{LO}}}\right)^{2}\left(\frac{1-\mathrm{x}}{\mathrm{x}}\right)^{0.3}$

$\Omega_{2}=0.2\left(\frac{\mu_{\mathrm{G}}}{\mu_{\mathrm{L}}}\right)^{0.4}$

$\Omega_{3}=0.4\left(\frac{\mathrm{x}}{1-\mathrm{x}}\right)^{0.3}+0.3 \mathrm{e}^{\frac{16}{\mathrm{Re}_{\mathrm{LO}}^{0.1}}}-0.4\left(\frac{\rho_{\mathrm{L}}}{\rho_{\mathrm{G}}}\right)^{0.2}$

Instead of using prediction methods, the developed measurement technique, under which flow boiling of R-236fa and R-245fa in rectangular micro-channels having hydraulic diameter of $0.148 \mathrm{~mm}$ was studied, was addressed by Costa-Patry et al. (2011) to measure the outlet pressure losses. As presented in Figs. 4 and 5, their measurements indicated that such pressure losses possessed up to $30 \%$ of the total pressure drop, tending to be non-negligible.

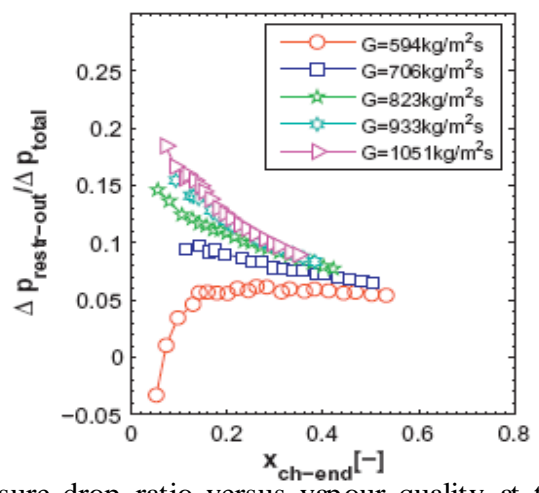

Fig. 4 Pressure drop ratio versus vapour quality at the end of the channel: R-236fa (Costa-Patry et al., 2011). "Reprinted from International Journal of Heat and Fluid Flow, 32(2), CostaPatry, E., Olivier, J., Nichita, B.A., Michel, B., and Thome, J.R., 2011, Two-phase flow of refrigerants in $85 \mu \mathrm{m}$-wide multi-microchannels: Part I - Pressure drop, pp. 451-463 (2011), with permission from Elsevier.”

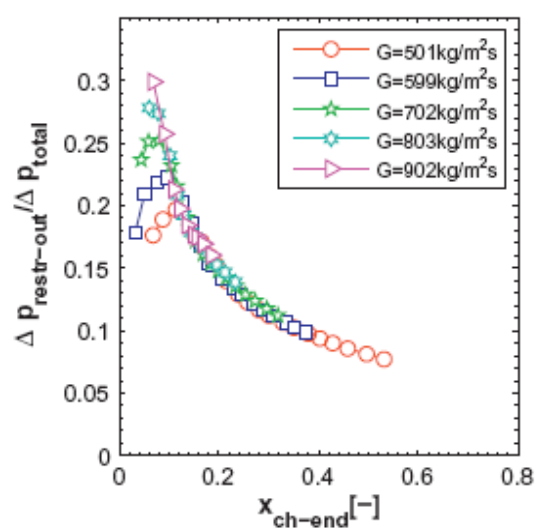

Fig. 5 Pressure drop ratio versus vapour quality at the end of the channel: R-245fa (Costa-Patry et al., 2011). "Reprinted from International Journal of Heat and Fluid Flow, 32(2), CostaPatry, E., Olivier, J., Nichita, B.A., Michel, B., and Thome, J.R., 2011, Two-phase flow of refrigerants in $85 \mu \mathrm{m}$-wide multi-microchannels: Part I - Pressure drop, pp. 451-463 (2011), with permission from Elsevier.”

Copetti et al. (2011) reported the two-phase pressure drop results of flow boiling experiment with R-134a flowing in a $2.6 \mathrm{~mm}$ diameter tube. The results showed relatively strong dependence of pressure drop on mass flux and vapour quality.

Soupremanien et al. (2011) indicated that aspect ratio had influence on pressure drop characteristics during flow boiling in rectangular channels. The pressure drop became lower as aspect ratio was decreased. In their work, the test sections with the same hydraulic diameter of $1.4 \mathrm{~mm}$ were examined.

In summary, this research field is still in its infancy. Although a number of studies have been reported for micro-channels, the pressure drop during micro-scale phenomena with respect to flow boiling mechanisms are still open questions for which systematic answers are of importance. Based on this, further investigations should be performed as follows.

1. Systematic flow boiling experiments should be carried out to obtain the macro-to-micro-scale transition. The threshold of the transition would be addressed according to the dependence of the channel orientation on pressure drop in addition to flow regime and heat transfer characteristics. 
2. Conduct more investigations for pressure change across inlet and outlet of the micro-channel evaporator to obtain precise prediction methods.

3. The existing models and correlations for two-phase pressure drop prediction should be examined based on different sources of the experimental data

4. Comparisons of flow boiling pressure drop characteristics in parallel channels with those in single channel should be performed under systematic parameters.

5. Void fraction is an important parameter for estimating twophase pressure drop. Several studies employed the existing correlations, based on ordinarily sized channels, to calculate void fractions which were subsequently used to evaluate the pressure drop in micro-channels. Instead of conventional correlations for macro-scale flow, the prediction method should be developed from the microchannel flow data. Recently, a small number of investigations were reported for micro-channel void fractions which were experimentally obtained, leading to the correlations. It is noted, however, that the experimental data mainly correspond to adiabatic two-phase gas-liquid flow systems. According to the lacking information, the flow boiling experiments with micro-channels should be designed to obtain the void fraction data for developing an approp riate correlation.

6. Several studies reported that separated flow model predicted well the pressure drop data. In contrast, the homogeneous flow assumption was also found to be in agreement with the measured results as reported by a number of publications. To meet a general conclusion, the systematic experiments during flow boiling in microchannels should be performed over a wide range of experimental conditions to identify when a given prediction method is applicable to the micro-scale flow boiling.

\section{CONCLUSION}

Recent studies on pressure drop during micro-scale flow boiling are reviewed in this article to provide information applicable for developing miniature flow devices. Although micro-scale flow has been defined by different criteria, the existing channel classifications cannot relate the channel diameter to the flow boiling mechanisms. On the basis of different previous investigations, the two-phase pressure drop characteristics in micro-channels are not completely compatible with those in ordinarily sized channels. Moreover, the existing two-phase pressure drop predictions are needed to be examined based on different sources of the experimental data.

\section{ACKNOWLEDGEMENTS}

The authors would like to express their appreciation to the Thailand Research Fund, KMITL Research Fund, the Office of Higher Education Commission and the National Research University Project for providing financial support.

\section{NOMENCLATURE}

$\mathrm{B}_{0} \quad$ bond number, $\mathrm{B}_{\mathrm{o}}=\mathrm{g}\left(\rho_{\mathrm{L}}-\rho_{\mathrm{G}}\right) \mathrm{D}^{2} / \sigma$

C Chisholm parameter

$\mathrm{C}_{\mathrm{o}} \quad$ confinement number as defined in Eq.(1)

D channel diameter $(\mathrm{m})$

$\mathrm{D}_{\mathrm{b}} \quad$ capillary length (m)

$\mathrm{D}_{\mathrm{h}} \quad$ hydraulic diameter $(\mathrm{m})$

f friction factor

G mass flux $\left(\mathrm{kg} / \mathrm{m}^{2} \mathrm{~s}\right)$

g gravitational acceleration $\left(\mathrm{m} / \mathrm{s}^{2}\right)$

$\mathrm{P} \quad$ pressure $(\mathrm{Pa})$

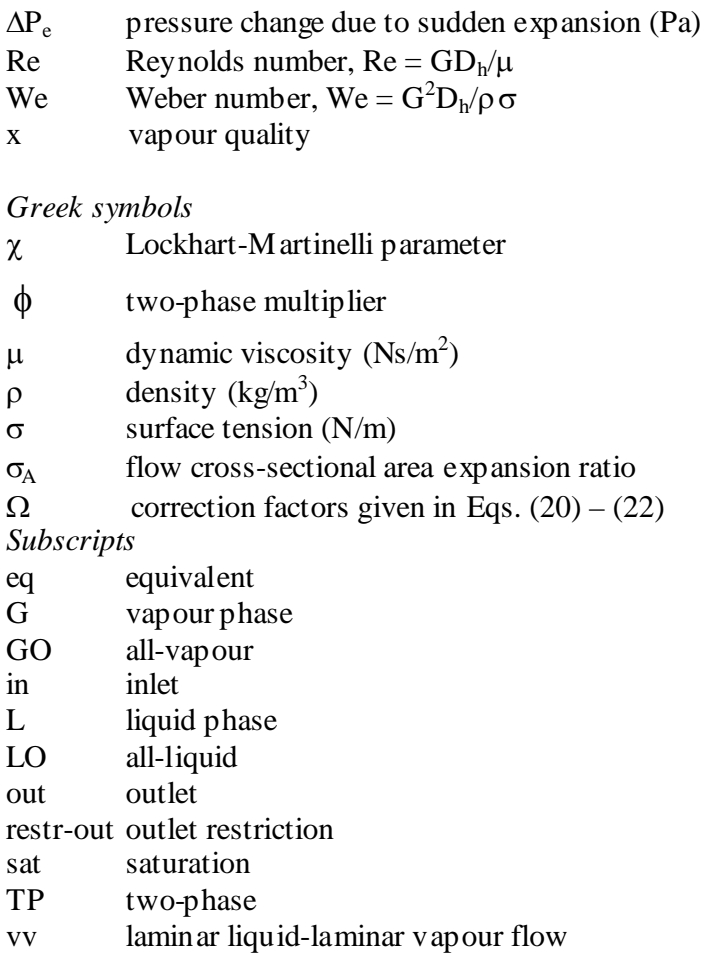

\section{REFERENCES}

Agostini, B., Revellin, R., Thome, J.R., Fabbri, M., Michel, B., Calmi, D., and Kloter, U., 2008, "High heat flux flow boiling in silicon multi-microchannels - Part III: Saturated critical heat flux of R236fa and two-phase pressure drops," International Journal of Heat and Mass Transfer, 51, 5426-5442.

http://dx.doi.org/10.1016/j.ijheatmasstransfer.2008.03.005

Beattie, D.H., and Whalley, P.B., 1982, "Simple two-phase frictional pressure drop calculation method," International Journal of Multiphase Flow, 8, 83-87.

http://dx.doi.org/10.1016/0301-9322(82)90009-X

Chen, I.Y., Tseng, C.-Y., Lin, Y.-T., and Wang, C.-C., 2009, “Twophase flow pressure change subject to sudden contraction in small rectangular channels," International Journal of Multiphase Flow, 35, 297-306.

http://dx.doi.org/10.1016/j.ijmultiphaseflow.2008.10.008

Choi, K-I., Pamitran, A.S., Oh, C.-Y., and Oh, J.-T., 2008, "Twophase pressure drop of R-410A in horizontal smooth minichannels," International Journal of Refrigeration, 31, 119-129. http://dx.doi.org/10.1016/j.ijrefrig.2007.06.006

Choi, K.-I., Pamitran, A.S., Oh, J.-T., and Saito, K., 2009, "Pressure drop and heat transfer during two-phase flow vap orization of propane in horizontal smooth minichannels," International Journal of Refrigeration, 32, 837-845.

http://dx.doi.org/10.1016/j.ijrefrig.2008.12.005

Copetti, J.B., Macagnan, M.H., Zinani, F., and Kunsler, N.L.F., 2011, "Flow boiling heat transfer and pressure drop of R-134a in a mini tube: an experimental investigation," Experimental Thermal and Fluid Science, 35, 636-644.

http://dx.doi.org/10.1016/j.exp thermflusci.2010.12.013

Costa-Patry, E., Olivier, J., Nichita, B.A., Michel, B., and Thome, J.R., 2011, "Two-phase flow of refrigerants in $85 \mu \mathrm{m}$-wide multi- 
microchannels: Part I - Pressure drop,” International Journal of Heat and Fluid Flow, 32, 451-463.

http://dx.doi.org/10.1016/j.ijheatfluidflow.2011.01.005

Kandlikar, S.G., 2010, "Scale effects on flow boiling heat transfer in microchannels: A fundamental perspective,” International Journal of Thermal Sciences, 49, 1073-1085.

http://dx.doi.org/10.1016/j.ijthermalsci.2009.12.016

Kew, P.A., and Cornwell, K., 1997, "Correlations for the prediction of boiling heat transfer in small-diameter channels," Applied Thermal Engineering, 17, 705-715.

http://dx.doi.org/10.1016/S1359-4311(96)00071-3

Lee, J., and Mudawar, I., 2005, "Two-phase flow in high-heat-flux micro-channel heat sink for refrigeration cooling applications: Part I - pressure drop characteristics," International Journal of Heat and Mass Transfer, 48, 928-940.

http://dx.doi.org/10.1016/i.ijheatmasstransfer.2004.09.018

Lee, P.-S., and Garimella, S.V., 2008, "Saturated flow boiling heat transfer and pressure drop in silicon microchannel arrays," International Journal of Heat and Mass Transfer, 51, 789-806. http://dx.doi.org/10.1016/j.ijheatmasstransfer.2007.04.019

Lee, H.J., Liu, D.Y., Alyousef, Y., and Yao, S., 2010, “Generalized two-phase pressure drop and heat transfer correlations in evaporative micro/minichannels,” Journal of Heat Transfer, 132, 1-9.

http://dx.doi.org/10.1115/1.4000861

Li, W., and Wu, Z., 2010a, "A general criterion for evaporative heat transfer in micro/mini-channels," International Journal of Heat and Mass Transfer, 53, 1967-1976.

http://dx.doi.org/10.1016/j.ijheatmasstransfer.2009.12.059

Li, W., and Wu, Z., 2010b, "A general correlation for adiabatic twophase pressure drop in micro/mini-channels," International Journal of Heat and Mass Transfer, 53, 2732-2739.

http://dx.doi.org/10.1016/j.ijheatmasstransfer.2010.02.029

Lie, Y.M., Su, F.Q., Lai, R.L., and Lin, T.F., 2008, “Experimental study of evaporation pressure drop characteristics of refrigerants R134a and R-407C in horizontal small tubes," International Journal of Heat and Mass Transfer, 51, 294-301.

http://dx.doi.org/10.1016/j.ijheatmasstransfer.2007.03.046

Mishima, K., and Hibiki, T., 1996, “Some characteristics of air-water two-phase flow in small diameter vertical tubes," International Journal of Multiphase Flow, 22, 703-712. http://dx.doi.org/10.1016/0301-9322(96)00010-9

Ong, C.L., and Thome, J.R., 2011, "Macro-to-microchannel transition in two-phase flow: Part 1-Two-phase flow patterns and film thickness measurements," Experimental Thermal and Fluid Science, 35, 37-47.

http://dx.doi.org/10.1016/i.expthermflusci.2010.08.004
Pamitran, A.S., Choi, K.-I., Oh, J.-T., and Oh, H.-K., 2008, "Twophase pressure drop during $\mathrm{CO}_{2}$ vaporization in horizontal smooth minichannels," International Journal of Refrigeration, 31, 13751383.

http://dx.doi.org/10.1016/j.ijrefrig.2008.04.004

Revellin, R., Dupont, V., Ursenbacher, T., Thome, J.R., and Zun, I., 2006, "Characterization of diabatic two-phase flows in microchannels: Flow parameter results for R134a in a $0.5 \mathrm{~mm}$ channel," International Journal of Multiphase Flow, 32, 755-774. http://dx.doi.org/10.1016/j.ijmultiphaseflow.2006.02.016

Ribatski, G., Wojtan, L., and Thome, J.R., 2006, “An analysis of experimental data and prediction methods for two-phase frictional pressure drop and flow boiling heat transfer in micro-scale channels," Experimental Thermal and Fluid Science, 31, 1-19.

http://dx.doi.org/10.1016/j.exp thermflusci.2006.01.006

Saisorn, S., Kaew-On, J., and Wongwises, S., 2010, "Flow pattern and heat transfer characteristics of R-134a refrigerant during flow boiling in a horizontal circular mini-channel," International Journal of Heat and Mass Transfer, 53, 4023-4038.

http://dx.doi.org/10.1016/j.ijheatmasstransfer.2010.05.022

Singh, S.G., Kulkarni, A., Duttagupta, S.P., Puranik, B.P., and Agrawal, A., 2008, "Impact of aspect ratio on flow boiling of water in rectangular microchannels," Experimental Thermal and Fluid Science, 33, 153-160.

http://dx.doi.org/10.1016/i.expthermflusci.2008.07.014

Soupremanien, U., Person, S.L., Favre-Marinet, M., and Bultel, Y., 2011, "Influence of the aspect ratio on boiling flows in rectangular mini-channels," Experimental Thermal and Fluid Science, 35, 797809.

http://dx.doi.org/10.1016/j.expthermflusci.2010.06.014

Sun, L., and Mishima, K., 2009, "Evaluation analysis of prediction methods for two-phase flow pressure drop in mini-channels," International Journal of Multiphase Flow, 35, 47-54. http://dx.doi.org/10.1016/j.ijmultiphaseflow.2008.08.003

Tibirica, C.B., and Ribatski, G., 2010, "Flow boiling heat transfer of R134a and R245fa in a $2.3 \mathrm{~mm}$ tube," International Journal of Heat and Mass Transfer, 53, 2459-2468.

http://dx.doi.org/10.1016/j.ijheatmasstransfer.2010.01.038

Wang, C.-C., Tseng, C.-Y., and Chen, I.Y., 2010, “A new correlation and the review of two-phase flow pressure change across sudden expansion in small channels," International Journal of Heat and Mass Transfer, 53, 4287-4295. http://dx.doi.org/10.1016/i.ijheatmasstransfer.2010.05.057

Zhang, W., Hibiki, T., and Mishima, K., 2010, "Correlations of twophase frictional pressure drop and void fraction in mini-channel," International Journal of Heat and Mass Transfer, 53, 453-465. http://dx.doi.org/10.1016/i.ijheatmasstransfer.2009.09.011 